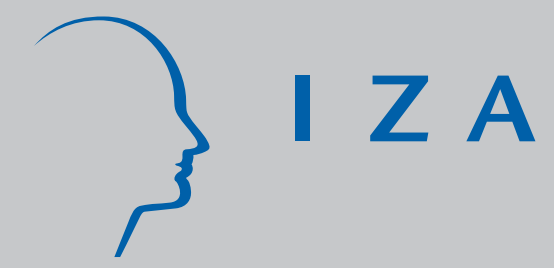

IZA DP No. 2417

Intergenerational Conflict, Partisan Politics, and Public Higher Education Spending:

Evidence from the German States

Ulrich Oberndorfer

Viktor Steiner

November 2006 


\title{
Intergenerational Conflict, Partisan Politics, and Public Higher Education Spending: Evidence from the German States
}

\author{
Ulrich Oberndorfer
}

ZEW Mannheim

Viktor Steiner

Free University Berlin, DIW Berlin

and IZA Bonn

\section{Discussion Paper No. 2417 \\ November 2006}

\author{
IZA \\ P.O. Box 7240 \\ 53072 Bonn \\ Germany \\ Phone: +49-228-3894-0 \\ Fax: +49-228-3894-180 \\ E-mail: iza@iza.org
}

\begin{abstract}
Any opinions expressed here are those of the author(s) and not those of the institute. Research disseminated by IZA may include views on policy, but the institute itself takes no institutional policy positions.

The Institute for the Study of Labor (IZA) in Bonn is a local and virtual international research center and a place of communication between science, politics and business. IZA is an independent nonprofit company supported by Deutsche Post World Net. The center is associated with the University of Bonn and offers a stimulating research environment through its research networks, research support, and visitors and doctoral programs. IZA engages in (i) original and internationally competitive research in all fields of labor economics, (ii) development of policy concepts, and (iii) dissemination of research results and concepts to the interested public.
\end{abstract}

IZA Discussion Papers often represent preliminary work and are circulated to encourage discussion. Citation of such a paper should account for its provisional character. A revised version may be available directly from the author. 
IZA Discussion Paper No. 2417

November 2006

\begin{abstract}
Intergenerational Conflict, Partisan Politics, and Public Higher Education Spending: Evidence from the German States*

We analyze potential effects of demographic change and political constellations on higher education spending. In our panel analysis of west German states (Laender) for the period 1985 to 2002 we find empirical evidence for the hypothesis of a negative relationship between demographic aging and spending on public higher education. In contrast to the hypothesis of the classical partisan theory that implies higher public expenditures under leftist parties, we find that governments under conservative parties or a coalition between social democrats and conservatives spend more on public higher education than governments run by the social-democratic party alone.
\end{abstract}

JEL Classification: H52, H72, 122

Keywords: demographic change, public higher education spending, partisan politics

Corresponding author:

Viktor Steiner

DIW Berlin

Koenigin-Luise-Strasse 5

14195 Berlin

Germany

E-mail: vsteiner@diw.de

\footnotetext{
* We thank Dirk Ulbricht and Friedhelm Pfeiffer for helpful comments and suggestions. Viktor Steiner acknowledges financial support from the German Science Foundation (Deutsche Forschungsgemeinschaft) under project STE 681/6-1.
} 


\section{$1 \quad$ Introduction}

The impact of demographic aging on public higher education spending has been studied much less than its potential effects on other public expenditure programs, such as social security or public health expenditures. Given the dominant role the public sector plays in the financing of higher education in most OECD countries, an important policy question is how demographic aging will affect the political economy of higher education finance in the future. Theoretical literature based on the median voter theory suggests negative effects of population aging on public education expenditure because of the growing relative importance of elderly voters. From a political perspective, the growing influence of the elderly on political decision-making in an aging society may result in an inefficiently low level of public expenditures on higher education with negative effects on economic growth and welfare.

However, demographic aging does not necessarily result in lower public education spending in democracies, as the inherent intergenerational conflict may be weakened by altruism between generations and economic externalities. Regarding such externalities, the elderly population may be interested in publicly financed educational investment in the hope to benefit later on by higher future incomes of former students and thus pension contributions, or from the services delivered by a better qualified work force. Furthermore, public education spending may not be determined solely by the preferences of the median voter, but rather according to the preferences or ideologies of different political parties, as suggested by the socalled partisan theory of political economy. The available empirical evidence mostly relates to the United States and suggests a negative relationship between public education expenditure and the population share of elderly people. There are relatively few empirical studies on the impact of political constellations on public expenditures, and these do not explicitly focus on higher education expenditures.

The present paper aims at filling this gap. In the next section we summarize theoretical and empirical literature on the relationship between public education spending and, 
respectively, demographic aging and political constellations. The empirical analysis of these relationships for the west German states is presented in section 3, which contains a description of the empirical methodology as well as the main results of our panel analysis. We find empirical evidence for the hypothesis of a negative relationship between demographic aging and higher spending on public education. Estimated effects of political constellations on public higher education spending do not support the hypothesis of the classical partisan theory that implies higher public expenditures under leftist parties. Instead, we find that governments under conservative parties or a coalition between social democrats and conservatives spend more on public higher education than governments run by social democrats alone. Section four concludes with a discussion of these findings.

\section{The Political Economy of Higher Education Spending}

\subsection{The Median Voter Theorem and Demographic Aging}

According to the median voter theorem (Downs, 1957), the government provides exactly the amount of a good, for example (higher) education, preferred by the median voter. The reason is that every political party competing with others in the democratic process has to adjust to the preferences of the median voter in order not to forgo the chance to win the election. The median voter theorem, however, requires the assumption of single peaked preferences. This assumption only holds if the demand for publicly provided education rises monotonously with income. For this condition to hold the income effect has to dominate the tax price effect (see Epple and Romano, 1996a, 1996b, Borck, 2006; for a recent review of the theoretical and empirical literature see Gradstein, Justman and Meier, 2005, chapter 4). This seems only plausible if there are no private alternatives to public higher education, since this condition implies that richer households prefer higher public education spending than poorer households at a higher relative price. Due to the fact that private alternatives to public higher education do exist - besides private domestic universities, studying abroad constitutes an 
alternative as well - the validity of the median voter theorem for higher public education is questionable.

The simple median voter theorem typically defines the median voter in terms of income only and thus neglects age as another important determinant of voters' preferences for public higher education spending. Since those benefiting from public education are typically young persons, age definitely plays a role here. Furthermore, young persons are often not employed and therefore pay only little income tax. The young generation, consequently, receives a transfer in form of education that is mainly financed by older persons via taxes. Furthermore, educational spending competes against other kinds of public spending, and especially with spending that the elderly can benefit from to a higher extent. Examples are transfers to the health care system or to the pension system. This rationale lends additional support to the hypothesis that the young generation prefers a higher amount of public (higher) education spending than the elderly do.

Nevertheless, this hypothesis is not uncontroversial; Poterba (1998) reviews the most important counter-arguments stressing two points: intergenerational altruism and externalities. Regarding the latter, investment in the educational system may enlarge the pool of resources from which the elderly could benefit later on by increasing future incomes of former students and thus pension contributions, for example. Furthermore, the quality of services that the elderly receive from younger workers could be raised. A very illustrating example of this effect is the education of students of medical science. This argument has its limits, though. Since the time period over which benefits from public higher education can be enjoyed diminishes with increasing age, the utility of the young generation derived from it is likely to be higher than of the older generation and this may again explain a negative relationship between age and the preferred amount of public education spending; Kemnitz (1999) presents a theoretical model rationalizing this argument. 
Gradstein and Kaganovich (2004) provide another theoretical perspective on the question whether demographic change leads to a decrease of public education spending. They identify an effect based on public choice arguments that works in the opposite direction. The authors suggest that the younger generation anticipates financial deficits of the pension system due to an inefficiently low level of education of the next generation. In relatively old societies, the young generation therefore would have an incentive to vote in favour of higher public education spending. This effect may even be stronger if increasing life expectancy is taken into account.

Although these arguments may weaken the inherent intergenerational conflict in the provision of public (higher) education spending, they seem unlikely to refute it completely, since diminishing preferences for publicly funded higher education will eventually occur, at least for the very old. For a given distribution of incomes, the increasing share of elderly people in the society changes the pivotal voter resulting in a reduced demand for higher education spending. Even if demographic aging does not affect the pivotal voter directly, it may result in higher inequality and a poorer median voter and thereby reduce the preferred level of higher education (Kemnitz, 1999).

Most empirical research concerning the demographic effects on public education spending has been undertaken for the US. Poterba (1997) finds some evidence for an intergenerational conflict concerning education spending in the United States. He shows that an increase in the share of elderly people ( $>65$ years) at the state level leads to a significant reduction of public school spending per pupil, with an estimated elasticity of -0.25 . Fernandez and Rogerson (2001) obtain similar results at the state level, while Ladd and Murray (2001) find a negative relationship between the share of the elderly and public-school spending at the state level, but not at the county level. Harris et al. (2001) also report negative effects of the share of elderly on public school spending at the district level. The estimated elasticity, however, is much smaller than the one obtained by Poterba (1997). 
For Germany, Baum and Seitz (2003) is hitherto the only study to empirically analyze the effect of demographic change on public education spending in Germany. Analyzing the per capita education spending at the municipal level for the west German states, they find only modest intergenerational effects which are statistically significant only if municipal and state spending are aggregated, or if the latter is consolidated at the municipal level. From an institutional point of view, however, using demographic indicators at the municipal level in order to explain state spending is not coherent, even if state spending is consolidated at the municipal level.

\subsection{Political Parties and Partisan Politics}

In the standard median voter model, preferences and ideologies of political parties do not play a role, since every political party has to adjust to the preferences of the median voter in order not to forgo the chance to win the election. In some amplifications of the model, however, party preferences (or ideologies) come into play. They cannot be eliminated by the power of the median voter if the elected candidates do not have to make binding commitments in the context of their pre-electoral platforms, as in Alesina (1988). The foundations of the partiesdo-matter-view, often referred to as partisan theory, were established by Hibbs (1977). He argues, in the context of the inflation-unemployment trade-off, that right-wing parties represent higher income groups that favour lower inflation rates, but are less interested in low unemployment rates. In contrast, left-wing parties plead for politics that are oriented towards the interests of low income groups. Following Hibbs, left-wing parties consequently favour higher public spending than right-wing parties do. The partisan theory can analogously be applied to specific types of public spending, e.g. on higher education.

There are numerous studies searching for empirical evidence supporting the partisan theory. Concerning aggregated public spending, e.g. Roubini and Sachs (1989), Blais, Blake, and Dion (1993), and Cusack (1997) find partisan effects for the OECD countries. Boix 
(1997), on the other hand, obtains significant party effects for public education spending for the OECD countries. According to his analysis, more than 40 per cent of the variation in public education spending in cross-section data for the 1970's can be explained by differences in political orientation of the respective governments. Here, leftist control of governments increases the part of education spending on GDP by 11 per cent. For the following decade, the author calculates fairly similar results that are statistically not significant, however.

Although there seems to exist no published study on the relationship between political constellations and higher public education spending for Germany, there are some related studies of interest we briefly summarize here. For the west German states, Seitz (2000) examines the relationship between public deficits and political constellations and finds no empirical evidence for party effects. Jochimsen and Nuscheler (2004) report similar results, although they also report the finding that the deficit growth declines in the years preceding state elections, which they interpret as evidence for 'political opportunism'. The strongest opportunism effects are found for political coalitions made up of the Social Democrats (SPD) and the Liberals (FDP). Regarding general partisan effects on public expenditures, Rodden (2001), using data from the west German states for 1974 to 1995, finds that conservative governments spend less and run smaller deficits than leftist governments do. Furthermore, he shows that the deficits rise in the years preceding elections, but in contrast to Jochimsen and Nuscheler (2004) finds no party differences in this respect. In yet unpublished work, Potrafke (2006) finds general partisan effects on state public expenditures, but no election or preelection effects.

\section{Panel Analysis for the German States}

\subsection{Institutional Background}

In Germany the states (Laender) are responsible for higher education, bearing almost 90 per cent of the total public spending for universities and related public institutions. The federal 
state only has to pay the costs related to construction, whereas the municipal authorities are not involved financially at all (cf. Seitz, Freigang, and Kempkes, 2005). On the revenue side, the main source of finance for the German states are tax revenues, the most important being the shares the states receive from income tax and the value-added tax. The distribution of the income tax between the different states depends on the tax revenues collected within the state borders. The value added tax, in contrast, is distributed according to the state population. Additionally, the states receive the total revenue of some taxes, e.g. of the motor vehicle tax. It is a distinctive feature of the German tax system that the states do not have the authority to levy taxes; tax rates are fixed by the federal government.

Since the primary distribution of the tax revenues would result in large differences between states in their ability to provide public goods, the fiscal system features mechanisms to reduce this inequality. In a first step (horizontaler Finanzausgleich), financial strength and financial needs of the states, measured by per-capita tax receipts, are partly equalized by distributing funds from states with high financial strength to those with high financial needs. In a second step, the federal government provides financial assistance to the poorer Laender (Fehlbetrags-Ergaenzungszuweisungen). In the end, the fiscal system results in an almost complete levelling of the tax revenues relative to needs between the states with the objective of an equal per-capita supply of public goods all over Germany.

\subsection{Data and Variables}

It the following empirical analysis we only consider the west German states (Laender) excluding Berlin. The east German states are not considered here since for them the analysis could only be conducted for the period after the German unification in 1991; furthermore, the first years after unification were dominated by enormous federally funded public infrastructure in the east German higher education system. Berlin is excluded due to the pronounced structural shift in the years 1991/92 given the extension of Berlin by its former 
eastern part. Furthermore, former west Berlin did not participate in the fiscal equalization mechanisms mentioned above but was directly funded by the federal state.

\section{Higher education spending}

The explanatory variable in the subsequent empirical analysis is real higher education spending (HES) per capita at the state level measured in prices of 1996; the observation period is 1985 to $2002 .{ }^{1}$ HES includes spending for teaching and research of public higher education institutions (Grundmittel), vocational training, and non-scientific training, as well as certain expenditures for hospitals attached to universities. We use higher education spending per capita rather than per student to avoid bias due to huge cost differences in expenditures per student across states and over time related to the varying importance. ${ }^{2}$ The underlying assumption for this normalization is that every German state can, in principle, spend the same per capita amount on higher education, as it could on any other public good, due to the system of fiscal equalization described above.

Figure 1 shows that expenditures per capita vary greatly across states, from roughly 120 Euro in Rhineland-Palatinate (RP) to 295 Euro per year in Hamburg (HH). Across all states, average real expenditures per year amounted to approximately 180 Euro in the observation period, with a standard deviation of about 50 Euro (see Table A1 in the appendix). Over the sample period, the level of higher education spending rose in most states, except for Bavaria (BY), Rhineland-Palatinate, and Schleswig-Holstein (SH). Public expenditures on higher education in the city states of Bremen (HB) and Hamburg are both higher and more volatile.

\footnotetext{
1 The German GDP deflator is used to calculate real expenditures.

2 To illustrate this point, students at German universities of art received Grundmittel funding of 12,400 Euro in 2001, while students at universities of applied sciences received only 4,300 Euro. Average costs per university student (medical institutions excluded) were 6,500 Euro, compared to an overall mean of 7,200 Euro. Compared across subject of studies, medical students required 28,400 Euro, while average costs per student of law, economics and social sciences were 2,070 Euro (see Statistisches Bundesamt (Federal Statistical Office), 2003).
} 


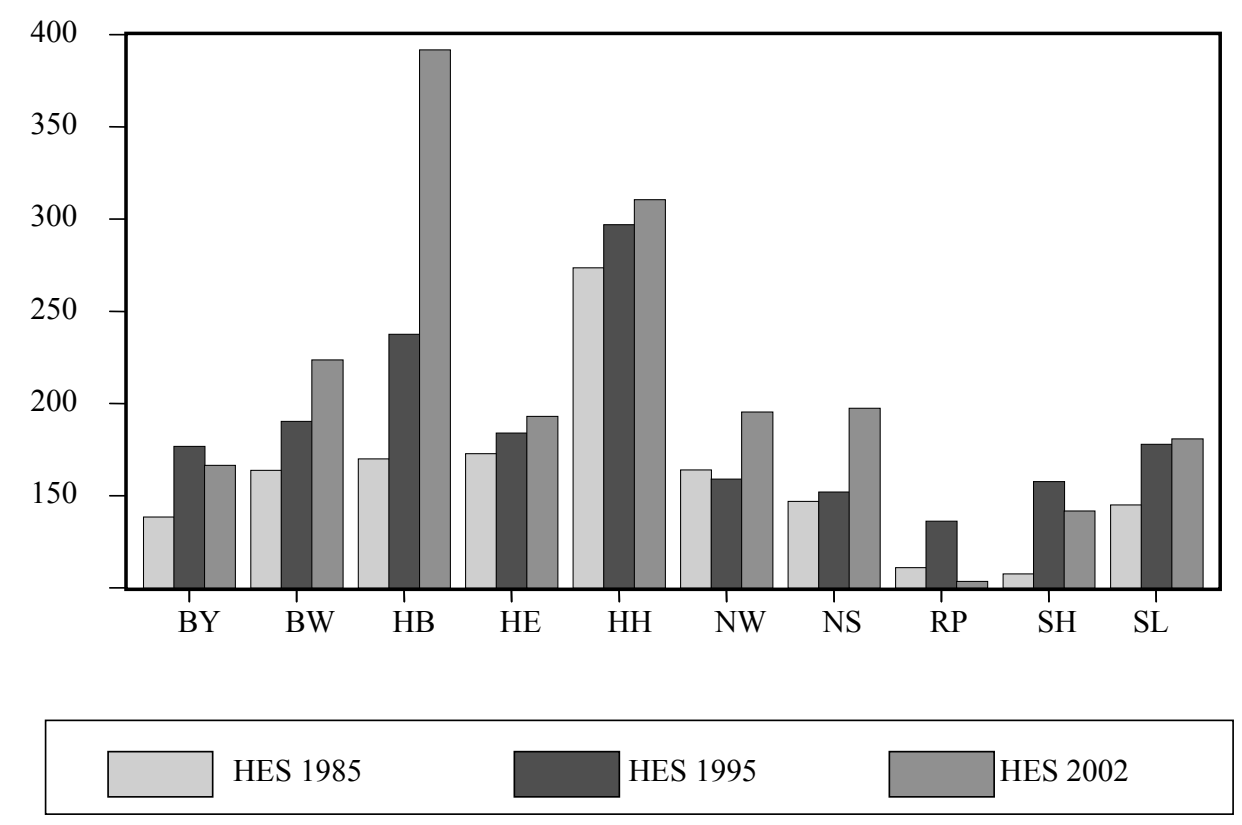

Source: Statistisches Bundesamt (Federal Statistical Office).

\section{Demography}

In order to proxy demographic change, we use two different definitions of population aging. The first definition - the population share of persons older than 65 years (see figure $2 \mathrm{a}$ ) follows the one adopted in most of the empirical literature reviewed in section 2.1 above. This definition is mainly motivated by the fact that people in this age group do not have children (still) attending higher education institutions. Altruism, which is hypothesized to attenuate intergenerational conflict in some of the literature reviewed above, may thus be less relevant within the population aged above 65 years. Since this age limit is somewhat arbitrary, however, we also use the population share of people older than 55 years to define population aging (see figure $2 \mathrm{~b}$ ). Since this alternative definition covers a much larger share in the population, we would expect more pronounced intergenerational effects due to the stronger political influence of this larger group. 
Figure 2. Population share of the elderly over the German states and the sample period

a) Population share of people older than 65 years

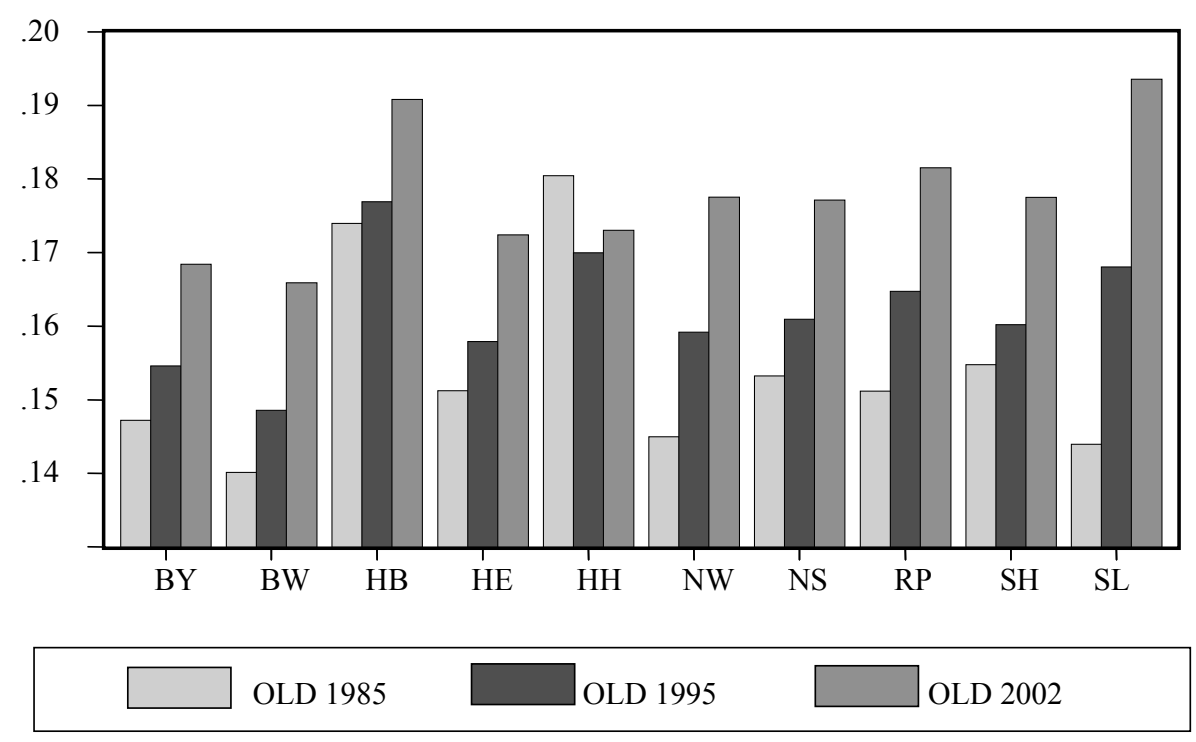

b) Population share of people older than 55 years

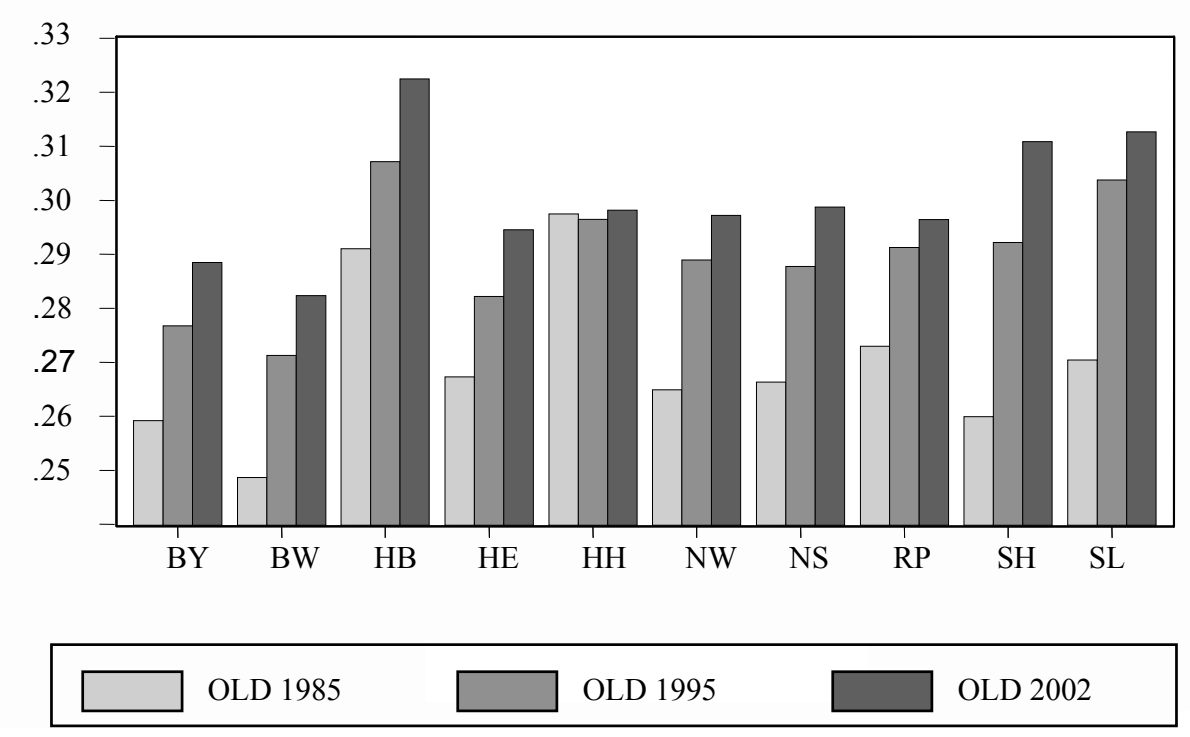

Source: Statistisches Bundesamt (Federal Statistical Office). 


\section{Political constellations ${ }^{3}$}

Very different constellations determined the policy in the German Laender between 1985 and 2002. The constellations considered in this paper are presented in Table 1. Further coalitions at the state level that occurred only once within the observation period or involved with only regional but no national relevance are not considered here.

Table 1. Political constellations in the west German states between 1985 and 2002

\begin{tabular}{|l|l|}
\hline Dummy variable & Political constellation (governing party and party coalitions) \\
\hline SPD (reference category) & $\begin{array}{l}\text { Sozialdemokratische Partei Deutschlands (Social Democratic } \\
\text { Party, SPD) } \\
\text { SPD, Buendnis 90/Die Gruenen (Green Party) } \\
\text { SPD-GR } \\
\text { SPD-CDU }\end{array}$ \\
SPD, Christlich-Demokratische Union (Christian Democratic \\
Party, CDU) \\
SPD, Freiheitlich-Demokratische Partei Deutschlands (Liberals, \\
FDU
\end{tabular}

The impact of the political constellations considered is measured using dummy variables taking on the value of one if the respective party or coalition of parties was governing a particular state in a given year, and zero otherwise; the Social Democratic Party (SPD) governing without any coalition partner is defined as the reference category. If the government changed within a particular year, the constellation that governed for a longer time period in this year is chosen. We do not distinguish between the two conservative parties CDU and CSU here, as both parties are very similar as far as programmatic orientation is concerned and the CSU only runs for election in the state of Bavaria, where the CDU stays absent.

\footnotetext{
${ }^{3}$ We thank Helge Berger, Free University Berlin, for making these data available to us.
} 


\section{Other variables affecting public higher education spending}

Expenditures on higher public education are also likely to be affected by structural differences between states, especially between the city states Bremen (HB) and Hamburg (HH) and the larger area states (Flaechenlaender). ${ }^{4}$ In addition to dummy variables accounting for timeinvariant state differences, we also control for time-varying differences related to the labour market situation, general economic conditions and a state's fiscal balance. To account for these differences, we include the unemployment rate, the level of average earnings, and the public debt per capita, all measured at the state level in a particular year, as control variables in the regression equations. Descriptive statistics of these variables are summarized in Table A1 in the appendix.

\subsection{Estimation Results}

Given the relatively small number of time series observations available for each state (yearly data for the period 1985 to 2002), it seems natural to pool data from the 10 west German states analyzed here and to apply standard panel estimation methods to exploit both crosssection (state) and time-series variation in the data. ${ }^{5}$ This requires, however, slope coefficients to be homogeneous across states. In a first step, we have checked this homogeneity assumption concerning the demographic variables by running simple time-series regressions for each state including a linear time trend. ${ }^{6}$ Measuring demographic aging by the population share of people older than 55 years, we could not reject the null hypothesis that regression coefficients of both the demographic variables and the time trend are not significantly different between states at the 5 percent level. Using the share of people older than 65 years

\footnotetext{
${ }^{4}$ These are Baden-Wuerttemberg (BW), Bavaria (BY), Hesse (HE), Nordrhine-Westphalia (NW), Lower Saxony (NS), Rhineland-Palatinate (RP), Schleswig-Holstein (SH), and the Saarland (SA).

${ }^{5}$ The commonly used (static) linear panel estimators are Pooled OLS, the Fixed Effects and the Random Effects Estimator (see, e.g., Greene, 2003, Chapter 13).

${ }^{6}$ The results of these time-series regressions are available on request.
} 
instead, in one case (the state of Lower Saxony) the homogeneity assumption was rejected both for the demographic variable and the time trend. We account for this in the panel estimation by including interaction terms between these two variables and a state dummy variable.

Estimation results based on Pooled OLS, Fixed Effects (FE), and Random Effects (RE) models are presented in Table A2 in the appendix. All regressions include a linear time trend, the control variables and the interaction terms for Lower Saxony mentioned above. In the final specification of the regression models, control variables were excluded from the model if estimated coefficients were not statistically significant at the $10 \%$-level. Pooled OLS estimations also include a dummy variable for Hamburg and Bremen to control for different expenditure patterns in city states. Since formal statistical tests indicate substantial autocorrelation in the residuals of static panel regressions (see Table A3 in the appendix), we also estimated the panel models using the Cochrane-Orcutt procedure to correct for first-order serial correlation (see, e.g., Greene, 2003, chapter 13.7.3). ${ }^{7}$ Finally, we tested for the existence of state fixed or random effects and whether or not these effects are correlated with the explanatory variables used in the respective models (see, e.g., Greene, 2003, Chapter 13.3. and 13.4.).

The results of these tests (see Table A4 in the appendix) indicate that there are significant state specific effects which are correlated with the explanatory variables included in the models. From these tests results we conclude that only the FE panel model would yield unbiased and - after correcting for autocorrelation - efficient parameter estimates. Estimation results for this model with the two alternative specifications of the demographic variable are summarized in Table 2.

\footnotetext{
${ }^{7}$ Autocorrelation in residuals may result from lagged adjustment of higher education spending relative to changes in the explanatory variables. Although a dynamic specification with lagged values of the dependent variable would perhaps have been more appropriate theoretically, estimating dynamic panel models would be problematic given the small number of observations in the cross-section (states). The statistical properties of dynamic panel estimators are not known in this case.
} 
Table 2. Estimated effects of demographic change and political constellations on public higher education spending of the German states - Fixed effects estimation with autocorrelation correction

\begin{tabular}{|c|c|c|c|c|c|c|}
\hline & \multirow[b]{2}{*}{ Demography } & \multicolumn{5}{|c|}{ Political constellations } \\
\hline & & $\begin{array}{l}\text { SPD- } \\
G R\end{array}$ & $\begin{array}{l}\text { SPD- } \\
F D P\end{array}$ & $\begin{array}{l}S P D- \\
C D U\end{array}$ & $\begin{array}{l}C D U- \\
F D P\end{array}$ & $C D U$ \\
\hline$>65$ years & $\begin{array}{c}-0.11 \\
(-0.30)\end{array}$ & $\begin{array}{l}0.02 \\
(1.35)\end{array}$ & $\begin{array}{l}0.01 \\
(0.35)\end{array}$ & $\begin{array}{l}0.08^{*} \\
(1.65)\end{array}$ & $\begin{array}{l}0.05 * * \\
(2.40)\end{array}$ & $\begin{array}{l}0.02 \\
(0.90)\end{array}$ \\
\hline$>55$ years & $\begin{array}{l}-1.22^{* *} \\
(-1.98)\end{array}$ & $\begin{array}{l}0.02 \\
(0.98)\end{array}$ & $\begin{array}{l}0.01 \\
(0.43)\end{array}$ & $\begin{array}{l}0.06 \\
(1.41)\end{array}$ & $\begin{array}{l}0.04 * \\
(1.66)\end{array}$ & $\begin{array}{l}0.02 \\
(0.80)\end{array}$ \\
\hline
\end{tabular}

Notes:

- the dependent variable is the log of state expenditures on public higher education; the demography variable is the log of the population share of people older than 65 and 55 years, respectively;

- t-values in brackets. * and ** indicate significance at a 10\%- and 5\%-level, respectively;

- estimations include the control variables mentioned in the text, except for the debt variable and the unemployment rate which are statistically insignificant in the specification with the share of persons older than 65 years;

- for full estimation results and test statistics see Tables A2 - A4 in the appendix.

For both specifications, the estimated impact of demographic aging on public higher education spending is negative, but the magnitude and statistical significance differ markedly between the two. If demographic change is proxied by the population share of people older than 65 years, the estimated coefficient is slightly negative, but statistically not significantly different from zero. In contrast, there is stronger evidence for an intergenerational conflict if demographic aging is measured by the share of people older than 55 years. The estimated coefficient is significant at the $5 \%$-level, the estimated elasticity is $-1.2{ }^{8}$ This implies that a rise of the population share of persons older than 55 years in a particular state reduces public higher education spending in that state by more than one percent.

Estimated effects of political constellations can be interpreted as percentage change from the level of higher education spending under a SPD government, which acts as the reference

\footnotetext{
${ }^{8}$ As the higher education spending variable as well as the demographic variables are measured in logarithmic form, estimated coefficients can directly be interpreted as elasticities.
} 
category. ${ }^{9}$ Hence, our results for the specification with the population share of people older than 65 years as proxy for demographic aging suggest that public spending on higher education in a state governed by a SPD-CDU coalition exceeded expenditures under a SPD government by 8 percent in the period 1985 to 2002 . If the alternative specification of the demographic variable is used, this effect is only 6 percent and statistically insignificant. For a CDU-FDP coalition we find a statistically significant effect of 5 (4) percent. Public expenditures on higher education in states governed by the conservatives (CDU) are lower than under a SPD government, but the difference is not statistically significant. Coalition governments between the SPD and the Green Party (SPD-GR) and the SPD and the Liberals (SPD-FDP) do no seem to behave differently from the SPD governing alone regarding higher public education expenditures.

\section{$4 \quad$ Summary and Conclusion}

We have discussed various reasons why demographic aging and political constellations may affect public spending on higher education in democracies. Theoretical literature based on the median voter theory suggests negative effects of population aging on public education expenditures, although there are counteracting forces and the empirical literature does not provide conclusive evidence on this relationship either. As suggested by the partisan theory, due to ideological reasons leftist parties prefer higher public spending than right-wing parties do. In this parties-do-matter-view the median voter does not restrict public expenditures, although the empirical evidence for such policy effects on public higher education is somewhat limited and inconclusive.

\footnotetext{
${ }^{9}$ Formally, the effect of a dummy variable $j$ referring to a particular political constellation on the dependent variable is measured as $\Delta \%=\left(\exp \left(\hat{\beta}_{j}\right)-1\right) * 100$, with $\hat{\beta}_{j}$ is estimated coefficient of the respective dummy variable .
} 
Using panel data for the west German states, we have analyzed if and to what extent demographic change as well as different political constellations impact on public spending on higher education. Regarding the impact of demographic aging, the empirical evidence is mixed. Whereas we do not find a significant impact if demographic aging is measured by the population share of people older than 65 years, we find a relatively strong and statistically significant effect if this variable is measured by the share of people older than 55 years. In our view, these diverging results can be explained by the larger size and thus greater political power of the latter relative to the former age group. In any case, our results for west German states suggest that certain intergenerational conflicts concerning higher education spending do exist.

Our empirical analysis also suggests that political constellations may affect the level of public spending on higher education, although these results do not support the partisan theory. In contrast, we find evidence for higher expenditures under conservative governments as well as under conservative and social-democratic coalitions, relative to periods governed by the social-democratic party alone. One reason for this result could be that, in contrast to what is implied by the partisan theory, the clientele of leftist parties profits relatively little from public expenditures on higher education; for Germany this may indeed be the case as the share of students with a parental background traditionally associated with the clientele of the Social Democratic Party is still rather small.

The evidence regarding the importance of political constellations suggests that not only fundamental economic factors or the median voter play a role in the determination of public spending on higher education. On the one hand, one can regret this result as it suggests the existence of education spending cycles influenced by purely political considerations. On the other hand, however, this result also implies that the voters do have a choice concerning higher education spending as it indicates that no policy convergence is reached. 


\section{References}

Alesina, A. (1988), Credibility and Policy Convergence in a Two-Party-System with Rational Voters, American Economic Review 78, 796-805.

Alt, J. and R. Lowry (1994), Divided Government, Fiscal Institutions, and Budget Deficits: Evidence from the States, American Political Science Review 88, 811-828.

Blais, A., D. Blake, and S. Dion (1993), Do Parties Make a Difference? Parties and the Size of Government in Liberal Democracies, American Journal of Political Science 37, 40-62.

Boix, C. (1997), Political Parties and the Supply Side of the Economy: The Provision of Physical and Human Capital in Advanced Economies 1960-90, American Journal of Political Science 41, 814-845.

Borck, R. (2006), Central versus Local Education Finance: A Political Economy Approach, DIW Discussion Papers No. 565/2006, Berlin.

Cusack, T. (1997), Partisan Politics and Public Finance: Changes in Public Spending in the Industrialized Democracies 1955-1989, Public Choice 91, 375-395.

Downs, A. (1957), An Economic Theory of Democracy, New York.

Epple, D. and R.E. Romano (1996a), Ends against the Middle: Determining Public Service Provision when there Are Private Alternatives, Journal of Public Economics 62, 297 325.

Epple, D. and R.E. Romano (1996b), Public Provision of Private Goods, Journal of Political Economy 104, 57-84.

Fernandez, R. and R. Rogerson (2001), The Determinants of Public Education Expenditures: Longer-Run-Evidence from the States, Journal of Education Finance 27, 567-584.

Gradstein, M. and M. Kaganovich (2004), Aging Population and Education Finance, Journal of Public Economics 88, 2469-2485.

Gradstein M., M. Justman and V. Meier (2005), The Political Economy of Education. Implications for Growth and Inequality, MIT Press.

Greene, W. (2003), Econometric Analysis, International Edition, $5^{\text {th }}$ Edition, Upper Saddle River.

Harris, A., W. Evans, and R. Schwab (2001), Education Spending in an Aging America, Journal of Public Economics 81, 449-472. 
Hibbs, D. (1977), Political Parties and Macroeconomic Policy, American Political Science Review 71, 1467-1487.

Jochimsen, B. and R. Nuscheler (2004), The Political Economy of the German Länder Deficit, Mimeo, Social Science Research Centre Berlin.

Kemnitz, A. (1999), Demographic Structure and the Political Economy of Education Subsidies, Public Choice 101, 235-249.

Ladd, H. and S. Murray (2001), Intergenerational Conflict Reconsidered: County Demographic Structure and the Demand for Public Education, Economics of Education Review 20, 343-357.

Olsen, M. (1965), The Logic of Collective Action, Cambridge.

Poterba, J. (1997), Demographic Structure and the Political Economy of Public Education, Journal of Policy Analysis and Management 16, 48-66.

Poterba, J. (1998), Demographic Change, Intergenerational Linkages, and Public Education, American Economic Association Papers and Proceedings 88, 315-320.

Potrafke, N. (2006), Parties Matter in Allocating Expenditures: Evidence from Germany, Mimeo, Department of Economics and Management Science, Humboldt University of Berlin.

Rodden, J. (2001), And the Last Shall be First: Federalism and Fiscal Outcomes in Germany, Mimeo, Massachusetts Institute of Technology.

Roubini, N. and J. Sachs (1989), Government Spending and Budget Deficits in the Industrial Countries, Economic Policy 12, 100-132.

Seitz, H. (2000), Fiscal Policy, Deficits and Politics of Subnational Governments: The Case of the German Laender, Public Choice 102, 183-218.

Seitz, H., D. Freigang, and G. Kempkes (2005), Demographic Change and Federal Systems, in: Färber, G. and N. Otter (Ed.), Spatial Aspects of Federative Systems, Speyerer Forschungsbericht 242, Speyer, 223-251.

Statistisches Bundesamt (Federal Statistical Office) (2003), Bericht zur finanziellen Lage der Hochschulen, Wiesbaden. 


\section{Appendix}

Table A1. Descriptive Statistics

\begin{tabular}{|c|c|c|c|c|c|c|c|c|c|c|c|c|c|}
\hline \multirow[t]{2}{*}{ State (Land) } & \multirow[t]{2}{*}{$\mathrm{T}$} & \multicolumn{2}{|c|}{$\begin{array}{l}\text { Higher education } \\
\text { spending per capita } \\
\text { (in Euro) }\end{array}$} & \multicolumn{2}{|c|}{$\begin{array}{l}\text { Population share of } \\
\text { people }>65 \text { years } \\
\text { (in } \%)\end{array}$} & \multicolumn{2}{|c|}{$\begin{array}{l}\text { Population share of } \\
\text { people }>55 \text { years } \\
\text { (in } \%)\end{array}$} & \multicolumn{2}{|c|}{$\begin{array}{l}\text { Unemployment rate } \\
\text { (in \%) }\end{array}$} & \multicolumn{2}{|c|}{$\begin{array}{l}\text { Average earnings } \\
\text { (in Euro) }\end{array}$} & \multicolumn{2}{|c|}{$\begin{array}{l}\text { Debt per capita } \\
\quad \text { (in Euro) }\end{array}$} \\
\hline & & M & SD & M & SD & M & SD & M & SD & M & SD & M & SD \\
\hline Bavaria & 18 & 165.82 & 15.29 & 0.15 & 0.01 & 0.27 & 0.01 & 8.34 & 1.45 & 30182.55 & 1860.04 & 1444.89 & 81.49 \\
\hline Baden-Württemberg & 18 & 187.02 & 14.41 & 0.15 & 0.01 & 0.27 & 0.01 & 6.01 & 1.49 & 31436.37 & 1653.40 & 2430.50 & 284.80 \\
\hline Bremen & 18 & 244.83 & 57.27 & 0.18 & 0.00 & 0.30 & 0.01 & 14.36 & 1.63 & 31485.79 & 1460.80 & 12525.18 & 1000.25 \\
\hline Hesse & 18 & 182.11 & 8.80 & 0.16 & 0.01 & 0.28 & 0.01 & 8.11 & 1.65 & 31864.80 & 1744.88 & 3080.16 & 387.50 \\
\hline Hamburg & 18 & 294.64 & 20.73 & 0.17 & 0.01 & 0.30 & 0.01 & 11.46 & 1.82 & 33056.10 & 1625.92 & 7761.17 & 1296.27 \\
\hline Lower Saxony & 18 & 157.76 & 16.68 & 0.16 & 0.01 & 0.28 & 0.01 & 11.95 & 1.70 & 29288.71 & 1197.99 & 3637.05 & 590.60 \\
\hline Nordrhine-Westphalia & 18 & 160.06 & 10.75 & 0.16 & 0.01 & 0.28 & 0.01 & 10.84 & 1.30 & 31171.94 & 1296.65 & 3638.92 & 462.58 \\
\hline Rhineland-Palatinate & 18 & 120.00 & 16.74 & 0.16 & 0.01 & 0.29 & 0.01 & 9.01 & 1.55 & 29364.07 & 1390.69 & 3710.22 & 593.95 \\
\hline Schleswig-Holstein & 18 & 145.48 & 11.59 & 0.16 & 0.01 & 0.28 & 0.02 & 10.89 & 1.49 & 27966.27 & 1413.11 & 4684.29 & 674.14 \\
\hline Saarland & 18 & 171.37 & 11.30 & 0.17 & 0.01 & 0.29 & 0.02 & 12.11 & 1.71 & 29392.22 & 1279.36 & 6050.96 & 716.14 \\
\hline $\mathrm{N} \times \mathrm{T}$ & 180 & 182.91 & 53.21 & 0.16 & 0.01 & 0.28 & 0.02 & 10.31 & 2.78 & 30520.88 & 2070.61 & 4896.34 & 3142.18 \\
\hline
\end{tabular}

Note: T: Number of observations (Years), M: Mean, SD: Standard deviation; the variables giving monetary values are given at the price level of 1996 (in Euro). 


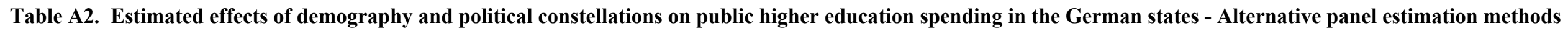

\begin{tabular}{|c|c|c|c|c|c|c|c|c|c|c|c|c|}
\hline & \multicolumn{2}{|c|}{ Pooled OLS } & \multicolumn{2}{|c|}{$\begin{array}{l}\text { Pooled OLS with } \\
\text { autocorrelation correction }\end{array}$} & \multicolumn{2}{|c|}{ Fixed Effects } & \multicolumn{2}{|c|}{$\begin{array}{l}\text { Fixed Effects with } \\
\text { autocorrelation correction }\end{array}$} & \multicolumn{2}{|c|}{ Random Effects } & \multicolumn{2}{|c|}{$\begin{array}{l}\text { Random Effects with } \\
\text { autocorrelation correction }\end{array}$} \\
\hline & $>65$ Years & $>55$ Years & $>65$ Years & $>55$ Years & $>65$ Years & $>55$ Jahre & $>65$ Years & $>55$ Years & $>65$ Years & $>55$ Years & $>65$ Years & $>55$ Years \\
\hline \multirow[t]{2}{*}{ Demography } & -0.10 & -0.13 & 0.08 & $-0.87 * *$ & $-0.47 * *$ & 0.21 & -0.11 & $-1.22 * *$ & -0.20 & 0.43 & $0.82 * *$ & $-1.01 *$ \\
\hline & $(-0.54)$ & $(-0.44)$ & $(0.25)$ & $(-2.45)$ & $(-2.33)$ & $(0.74)$ & $(-0.30)$ & $(-1.98)$ & $(-0.92)$ & $(1.17)$ & $(2.39)$ & $(-1.88)$ \\
\hline \multirow[t]{2}{*}{ SPD-GR } & -0.02 & -0.03 & 0.03 & 0.02 & 0.02 & -0.004 & 0.02 & 0.02 & - & - & - & - \\
\hline & $(-1.08)$ & $(-1.58)$ & (1.44) & $(1.01)$ & $(0.64)$ & $(-0.23)$ & $(1.35)$ & $(0.98)$ & & & & \\
\hline \multirow[t]{2}{*}{ SPD-FDP } & $-0.21 * * *$ & $-0.22 * *$ & -0.04 & -0.04 & 0.02 & -0.01 & 0.01 & 0.01 & - & - & - & - \\
\hline & $(-4.27)$ & $(-4.04)$ & $(-1.13)$ & $(-1.21)$ & $(0.56)$ & $(-0.40)$ & $(0.35)$ & $(0.43)$ & & & & \\
\hline \multirow[t]{2}{*}{ SPD-CDU } & 0.03 & 0.03 & 0.05 & 0.04 & $0.15^{* * *}$ & $0.16^{* * *}$ & $0.08^{*}$ & 0.06 & $0.17 * * *$ & $0.18^{* * *}$ & 0.02 & $0.05^{*}$ \\
\hline & $(0.60)$ & $(0.67)$ & $(0.96)$ & $(0.89)$ & (2.89) & $(3.49)$ & $(1.65)$ & $(1.41)$ & $(3.40)$ & $(5.76)$ & $(1.36)$ & (1.87) \\
\hline \multirow[t]{2}{*}{ CDU-FDP } & 0.0007 & -0.006 & $0.05 * *$ & $0.04 *$ & $0.07 *$ & $0.05^{* *}$ & $0.05 * *$ & $0.04 *$ & $0.07 * * *$ & $0.08 * * *$ & 0.02 & $0.03^{*}$ \\
\hline & $(0.03)$ & $(-0.34)$ & $(2.44)$ & $(1.91)$ & (1.84) & (2.39) & $(2.40)$ & $(1.66)$ & $(2.91)$ & $(3.42)$ & $(1.48)$ & $(1.96)$ \\
\hline \multirow[t]{2}{*}{ CDU } & 0.003 & -0.005 & $0.05^{* *}$ & $0.04 * *$ & -0.07 & -0.06 & 0.02 & 0.02 & 0.01 & $0.09 * * *$ & 0.05 & 0.03 \\
\hline & $(0.11)$ & $(-0.22)$ & $(2.00)$ & $(2.05)$ & $(-0.30)$ & $(-0.27)$ & $(0.90)$ & $(0.80)$ & $(0.36)$ & (3.49) & $(0.41)$ & $(2.52)$ \\
\hline $\mathrm{R}^{2}$ & 0.81 & 0.81 & 0.46 & 0.44 & 0.92 & 0.91 & 0.70 & 0.62 & 0.43 & 0.52 & 0.09 & 0.12 \\
\hline
\end{tabular}

Notes:

- $\quad \mathrm{t}$-values in brackets (White heteroskedasticity-robust standard errrors); *, ** and *** show significance at the 10\%-, 5\%-, and 1\%-level, respectively;

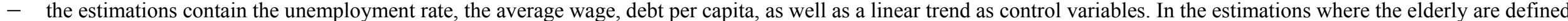
as the persons older than 65 , the time trend as well as the demographic variable are furthermore interacted with a dummy variable for the state of Lower Saxony. The control variables representing structural changes in the economy are excluded from the estimation, however, if not significant at the $10 \%$-level.

- Number of observations $=180$ (10 states $\times 18$ years $)$. 
Table A3. Test of first-order autocorrelation in residuals

\begin{tabular}{|l|c|c|c|}
\hline Demographic variable & Pooled OLS & Fixed Effects & Random Effects \\
\hline$>$ 65 years & $\begin{array}{r}0.78^{* * *} \\
(11.12)\end{array}$ & $\begin{array}{r}0.68^{* * *} \\
(6.01)\end{array}$ & $\begin{array}{r}0.87 * * * \\
(11.77)\end{array}$ \\
\hline$>55$ years & $\begin{array}{r}0.78^{* * *} \\
(11.34)\end{array}$ & $\begin{array}{r}0.73 * * * \\
(6.93)\end{array}$ & $\begin{array}{r}0.83 * * * \\
(9.60)\end{array}$ \\
\hline
\end{tabular}

Notes:

- t-values in brackets (White heteroskedasticity-robust variance); *** indicates significance at the 10\%-level;

- residuals from the estimations given in Table A2 are used for the autocorrelation correction (CochraneOrcutt procedure); the regressions contain a constant term as well as the first two lagged values of the estimated residuals; no significant autocorrelation of $2^{\text {nd }}$ order could be detected in any of the estimated models.

Table A4. Panel tests

\begin{tabular}{|l|c|c|c|}
\hline $\begin{array}{l}\text { Specification of the } \\
\text { demographic variable }\end{array}$ & $\begin{array}{c}\text { F-test for fixed } \\
\text { state effects }\end{array}$ & $\begin{array}{c}\text { LM-test for random } \\
\text { state effects }\end{array}$ & Hausman Test \\
\hline$>\mathbf{6 5}$ years & $37.15 * * *$ & $132.29 * * *$ & $37.19 * * *$ \\
\hline$>\mathbf{5 5}$ years & $33.82 * * *$ & $131.60 * * *$ & $30.22 * * *$ \\
\hline
\end{tabular}

Note: *** shows significance at a 1\%-level; tests based on the estimations given in Table A2. 